\title{
Efeito da idade de corte sobre a composição bromatológica e as características da silagem de cana-de-açúcar plantada em dois espaçamentos e três idades de corte
}

\author{
Gisele Bonato Muraro ${ }^{1^{*}}$, Paulo Rossi Junior ${ }^{2}$, Vinícius Chimenez de Oliveira ${ }^{3}$, Pedro Marcos \\ de Carli Granzotto ${ }^{3}$, Ana Luiza Bachmann Schogor ${ }^{4}$
}

\footnotetext{
1 Programa de Pós-graduação em Ciências Veterinárias - UFPR

2 Departamento de Zootecnia - UFPR.

${ }^{3}$ Estagiários do Departamento de Zootecnia - UFPR.

${ }^{4}$ Programa de Pós-graduação em Zootecnia - UEM.
}

RESUMO - Objetivou-se identificar os efeitos dos espaçamentos de plantio (0,90 m e 1,30 m entre linhas) e da idade de corte na composição bromatológica e nas características da silagem de cana-de-açúcar, variedade RB72-454. O experimento foi realizado no período de novembro de 2004 a janeiro de 2006. Os tratamentos foram constituídos da combinação dos espaçamentos de $0,90 \mathrm{~m}$ e 1,30 m com as idades de corte de 240 (cana-planta), 180 (rebrote) e 420 dias (cana-planta). O delineamento estatístico utilizado foi em blocos ao acaso, com cinco repetições por combinação de espaçamento e idade de corte. Como silos experimentais, foram utilizados tubos de PVC com tampas próprias para vedação, que, depois de fechados, foram armazenados em lugar arejado por 90 dias. A análise dos dados comprovou não haver efeito significativo do espaçamento de plantio sobre as características bromatológicas da cana-de-açúcar. A idade de corte teve efeito significativo nos teores de matéria seca, proteína bruta, resíduo mineral, fibra em detergente neutro, fibra em detergente ácido, lignina e ${ }^{\circ}$ brix. Com o aumento da idade de corte, houve redução dos constituintes da parede celular, em virtude do acúmulo de carboidratos solúveis. A silagem apresentou aumento do teor de proteína e dos constituintes da parede celular, em virtude da utilização dos carboidratos solúveis no processo de fermentação. As características químico-bromatológicas não foram alteradas pela redução do espaçamento de plantio. O corte da cana-de-açúcar aos 240 e 180 dias acarreta maiores perdas nutritivas no processo de ensilagem.

Palavras-chave: ensilagem, fibra, parâmetros fermentativos, Saccharum spp

\section{Effect of age at harvesting on the nutritive value and characteristics of sugarcane silage grown in two row spacings and three harvesting ages}

\begin{abstract}
The objective of this experiment was to identify the effect of row spacing $(0.90 \mathrm{~m}$ and $1.30 \mathrm{~m})$ and harvesting ages on the chemical composition and characteristics of sugarcane silage and productivity of the RB72-454 variety sugarcane. The experiment was carried out from November 2004 to January 2006. Treatments consisted of a combination of $0.90 \mathrm{~m}$ and $1.30 \mathrm{~m}$ row spacing and harvesting ages were 240 days (plant-cane), 180 days (regrowth) and 420 days (plant-cane). A randomized block experimental design was used, with five replications per treatment. The experimental silos were PVC pipes with individual covers, stored in a ventilated place for 90 days. The data analysis demonstrated there was no significant effect of the row spacing on the sugarcane chemical composition. The harvest age had significant effect on contents of dry matter, crude protein, mineral, neutral fiber detergent, acid fiber detergent, lignin and ${ }^{\circ}$ brix. Reduction in the cell wall constituents was observed with the maturation of the plant, because of the increase in soluble carbohydrates. The silage showed increased protein content and cellular wall constituent because of the use of the soluble carbohydrates in the fermentation process. The nutritive composition not was affected by row spacing. Sugar cane harvesting at 240 and 180 days resulted in greater nutritive losses during ensiling.
\end{abstract}

Key Words: ensilage, fermentative parameters, fiber, Saccharum spp

Este artigo foi recebido em 27/3/2007 e aprovado em 20/10/2008.

Correspondências devem ser enviadas para: giselemuraro@terra.com.br

*Endereço atual: Escola Superior de Agricultura "Luiz de Queiroz" - USP. Programa de Pós-Graduação em Ciência Animal e Pastagem. Av. Pádua Dias, 11, Caixa postal 9, CEP: 13418-900, Piracicaba, SP. 


\section{Introdução}

A cana-de-açúcar tem atraído a atenção dos pecuaristas e se tornado um volumoso de uso preferencial, principalmente nos confinamentos para terminação de bovinos de corte, por apresentar características como facilidade de cultivo, altas produções de forragem por unidade de área, persistência, baixo custo por unidade de matéria seca produzida e manutenção do valor nutritivo por 4-6 meses após a maturação, época recomendada para colheita no período de escassez de forragem.

Há muito se preconiza que a melhor variedade de canade-açúcar para a indústria de açúcar é também a melhor para ser utilizada como forrageira, pois apresenta maior teor de açúcar, interessante na alimentação animal. No entanto, existem numerosas variedades de cana-de-açúcar com características bastante diversificadas e, especificamente quando se destina à alimentação animal, as principais características são a produção de matéria seca (cana-planta e cana-soca), a facilidade de colheita e a qualidade nutritiva, que inclui não somente o teor de açúcar, mas também a qualidade da fibra (Freitas et al., 2006a).

A utilização de cana-de-açúcar ensilada tem sido uma alternativa à capineira, que exige cortes diários da forragem. De acordo com Nussio et al. (2006), os principais motivos para a adoção dessa tecnologia são a concentração de atividades de colheita, que podem ser terceirizadas em um período curto, a redução dos custos com transporte na fazenda e a redução na necessidade diária de mão-de-obra. Além disso, o aumento da longevidade do talhão, decorrente da melhor execução de práticas agronômicas de manejo, também constitui benefício. Ressalta-se que a ensilagem de cana-de-açúcar apresenta fermentação tipicamente alcoólica, ocasionando perdas no valor nutritivo oriundas do processo de fermentação.

O objetivo com este trabalho foi avaliar a composição bromatológica da cana-de-açúcar, variedade RB72-454, in natura e ensilada, plantada em dois espaçamentos $(0,90 \mathrm{~m}$ e $1,30 \mathrm{~m})$ e submetida ao corte em três idades de corte (180, 240 e 420 dias de crescimento).

\section{Material e Métodos}

Os trabalhos foram conduzidos em três propriedades localizadas no município de Santo Antônio da Platina no estado do Paraná. A área experimental constou de dois talhões de 1 ha em cada uma das propriedades. O clima da região, segundo a classificação de Koppen, é Cfa, subtropical. O solo é classificado como argissolo vermelho de relevo levemente ondulado.
A área foi delimitada por estacas de madeira, respeitando bordadura de 5 linhas de plantio em cada lado do talhão. As áreas escolhidas estavam sob mesma condição de relevo, com os mesmos tratos culturais e de adubação e estão localizadas em um raio de aproximadamente $5 \mathrm{~km}$.

Foi realizada adubação de plantio com $60 \mathrm{~kg}$ de $\mathrm{P}_{2} \mathrm{O}_{5} \mathrm{e}$ $100 \mathrm{~kg}$ de $\mathrm{KCl}$ por hectare. No talhão correspondente aos cortes de 240 e 420 dias, foi feita adubação de cobertura com 45 kg de nitrogênio por hectare em fevereiro de 2005 e, no talhão correspondente ao corte com 180 dias, foi feita nova adubação de cobertura com $45 \mathrm{~kg}$ de nitrogênio e $45 \mathrm{~kg}$ KCl em outubro de 2005.

Os tratamentos (combinações de espaçamento de plantio e idade de corte) foram distribuídos em delineamento de blocos ao acaso, com cinco repetições. Os espaçamentos testados foram de 0,90 m e 1,30 m entre linhas e as idades de corte, de 180 dias para cana-soca, 240 para cana-planta e 420 dias para cana-planta. O primeiro corte foi realizado em julho, com a cana-planta de 240 dias de desenvolvimento, e o segundo, em janeiro para a cana-de-açúcar de 180 dias de rebrota e 420 dias de cana-planta.

Foram escolhidas cinco linhas de plantio, consecutivas para cada espaçamento testado, de $10 \mathrm{~m}$ cada uma. Cortaram-se manualmente 20 perfilhos, rente ao solo, em cada linha, formando um feixe correspondente a cada linha de plantio. Foi mensurado o ${ }^{\circ}$ brix por meio do refratômetro de campo (marca TOKYO ${ }^{\circledR}$ modelo 032).

Os feixes foram pesados e depois cortados a $20 \mathrm{~cm}$ da base do perfilho (tocos) para simulação do corte mecanizado. Os feixes e os tocos foram picados separadamente, sem a retirada da palha, utilizando-se picadora de forragem, modelo estacionário, de modo que as partículas tivessem tamanho entre 1 e $2 \mathrm{~cm}$.

Como silos experimentais foram utilizados tubos de PVC com $10 \mathrm{~cm}$ de diâmetro e $60 \mathrm{~cm}$ de comprimento. Uma extremidade do silo foi fechada com tampa própria à vedação e a outra, com duas lonas plásticas, e lacradas com fita plástica. A silagem foi confeccionada com a parte do feixe sem os tocos, que foram picados juntamente com a palhada, em picadeira modelo estacionário, em partículas de aproximadamente 1-2 cm. A compactação foi feita com soquete de madeira em camadas de 5 a $10 \mathrm{~cm}$ de espessura, atingindo $550 \mathrm{~kg} / \mathrm{m}^{3}$ por silo. Após a ensilagem, os silos experimentais foram guardados em pé em local coberto, sob temperatura ambiente, até o momento da abertura.

Amostras da cana-de-açúcar fresca foram colhidas dos feixes e dos tocos e preparadas para determinação do teor de matéria seca, após pré-secagem a $60^{\circ} \mathrm{C}$ em estufa com ventilação forçada. Depois de secas, foram trituradas em moinho tipo Willey com peneira de $1 \mathrm{~mm}$. Nas amostras 
secas da fração feixe e toco, foram analisados os teores de umidade, proteína bruta, extrato etéreo e cinzas, segundo AOAC (1990). Também foram determinados os componentes: fibra em detergente neutro, fibra em detergente ácido e lignina, de acordo com metodologia proposta por Goering \& Van Soest (1970).

Os silos foram abertos após 90 dias da ensilagem e amostras foram colhidas desprezando-se as porções das extremidades do silo ( $10 \mathrm{~cm}$ em cada extremidade), considerando apenas a parte central da massa ensilada, que foi homogeneizada para retirada de amostra. As amostras utilizadas nas análises químico-bromatológicas foram secas em estufa com ventilação forçada a $60^{\circ} \mathrm{C}$, trituradas em moinho tipo Willey, com peneira de $1 \mathrm{~mm}$, secas e analisadas para determinação da umidade e do teor de proteína bruta, de acordo com a AOAC (1990). Também foram determinados os componentes: fibra em detergente neutro, fibra em detergente ácido e lignina, de acordo com metodologia proposta por Goering \& Van Soest (1970).

Para determinação do $\mathrm{pH}$ da silagem, $25 \mathrm{~g}$ de amostra úmida da silagem foram processados com $225 \mathrm{~mL}$ de água destilada, em liquidificador, durante um minuto. Em seguida, $\mathrm{o} \mathrm{pH}$ foi determinado no extrato utilizando-se um potenciômetro digital da marca Digimed ${ }^{\circledR}$, modelo DM 20. O nitrogênio amoniacal da silagem foi determinado conforme metodologia proposta por Silva \& Queiroz (2002).

O delineamento experimental utilizado foi o de blocos ao acaso, de modo que cada fazenda representou um bloco com cinco repetições por tratamento. Os dados experimentais foram analisados estatisticamente pelos procedimentos de análise de variância, por meio do programa Statistica 6.0. Para efeito de comparação de médias, foi utilizado o teste Tukey, a 5\% de probabilidade.

\section{Resultados e Discussão}

Os blocos apresentaram diferenças estatísticas entre si e os dados dos blocos estão apresentados na forma de média (Tabela 1). Na fração feixe, foi detectado efeito de fazenda sobre os teores de matéria seca, matéria mineral, proteína bruta, fibra em detergente neutro e lignina. Na fração toco, houve efeito sobre os teores de matéria mineral, proteína bruta e fibra em detergente neutro e, nas silagens, sobre os teores de matéria seca, proteína bruta, fibra em detergente neutro, lignina, $\mathrm{pH}$ e nitrogênio amoniacal.

Tabela 1 - Composição química da frações feixe e toco e da silagem de cana-de-açúcar variedade RB72-454

\begin{tabular}{|c|c|c|c|c|c|c|c|}
\hline & \multicolumn{2}{|c|}{180 dias } & \multicolumn{2}{|c|}{240 dias } & \multicolumn{2}{|c|}{420 dias } & \multirow[t]{2}{*}{$\mathrm{EPM}^{1}$} \\
\hline & $0,90 \mathrm{~m}$ & $1,30 \mathrm{~m}$ & $0,90 \mathrm{~m}$ & $1,30 \mathrm{~m}$ & $0,90 \mathrm{~m}$ & $1,30 \mathrm{~m}$ & \\
\hline Componente & \multicolumn{6}{|c|}{ Feixe } & \\
\hline Matéria seca, MS (\%) & $16,00 \mathrm{c}$ & $16,63 \mathrm{c}$ & $21,30 b$ & $21,90 b$ & $25,48 \mathrm{a}$ & $25,15 \mathrm{a}$ & 0,143 \\
\hline${ }^{\circ}$ Brix & $6,27 c$ & $6,90 c$ & $10,21 b$ & $10,86 b$ & $16,86 a$ & $17,45 a$ & 0,280 \\
\hline Matéria mineral (\%) & $7,08 \mathrm{a}$ & $7,25 a$ & $6,27 b$ & $6,05 b$ & $4,79 c$ & $4,41 \mathrm{c}$ & 0,126 \\
\hline Extrato etéreo (\%) & $2,75 a$ & $2,85 a$ & $2,25 b$ & $2,07 b$ & $2,02 b$ & $2,14 b$ & 0,046 \\
\hline Proteína bruta (\%) & $5,37 c$ & $5,62 \mathrm{bc}$ & $6,34 \mathrm{a}$ & $6,03 \mathrm{ab}$ & $3,44 d$ & $3,50 \mathrm{~d}$ & 0,091 \\
\hline Fibra em detergente neutro (\%) & $75,93 a$ & $75,29 a$ & $69,00 \mathrm{~b}$ & $67,27 b$ & $59,99 c$ & $60,77 \mathrm{c}$ & 0,359 \\
\hline Fibra em detergente ácido, FDA (\%) & $43,56 a$ & $43,62 \mathrm{a}$ & $42,10 \mathrm{a}$ & $43,04 \mathrm{a}$ & $36,61 b$ & $35,84 b$ & 0,301 \\
\hline \multirow[t]{2}{*}{ Lignina (\% da FDA) } & $5,75 \mathrm{bc}$ & $4,77 \mathrm{c}$ & $7,00 \mathrm{ab}$ & $7,40 \mathrm{a}$ & $5,26 c$ & $4,46 c$ & 0,177 \\
\hline & \multicolumn{6}{|c|}{ Toсо } & \\
\hline Matéria seca (\%) & $15,99 c$ & $16,63 \mathrm{c}$ & $23,09 b$ & $24,60 \mathrm{ab}$ & $25,10 a$ & $25,47 a$ & 0,200 \\
\hline Matéria mineral (\%) & $5,40 \mathrm{a}$ & $5,15 a$ & $3,89 b$ & 3,03bc & $3,29 b c$ & $2,50 \mathrm{c}$ & 0,137 \\
\hline Extrato etéreo (\%) & $2,01 \mathrm{a}$ & $1,87 \mathrm{a}$ & $1,48 b$ & $1,29 b$ & $1,49 b$ & $1,35 b$ & 0,029 \\
\hline Proteína bruta (\%) & $3,26 \mathrm{c}$ & $3,82 \mathrm{bc}$ & $5,10 \mathrm{a}$ & $4,30 \mathrm{~b}$ & $2,96 \mathrm{c}$ & $2,92 \mathrm{c}$ & 0,085 \\
\hline Fibra em detergente neutro (\%) & $62,84 \mathrm{a}$ & $61,20 \mathrm{a}$ & $53,03 b$ & $49,66 c$ & $49,23 c$ & $50,28 c$ & 0,430 \\
\hline Fibra em detergente ácido (\%) & $37,90 a$ & $36,95 a$ & $34,03 b$ & $31,26 c$ & $31,21 \mathrm{c}$ & $31,67 c$ & 0,288 \\
\hline \multirow[t]{2}{*}{ Lignina (\% da FDA) } & $4,10 \mathrm{~b}$ & $4,24 b$ & $5,96 a$ & $5,05 \mathrm{ab}$ & $4,03 b$ & $5,11 \mathrm{ab}$ & 0,156 \\
\hline & \multicolumn{6}{|c|}{ Silagem } & \\
\hline Matéria seca (\%) & $17,97 \mathrm{c}$ & $18,85 \mathrm{c}$ & $20,19 b$ & $20,54 b$ & $24,29 a$ & 23,18ab & 0,295 \\
\hline Proteína bruta (\% da MS) & $5,04 b$ & $5,40 \mathrm{~b}$ & $6,37 a$ & $6,11 \mathrm{a}$ & $3,71 \mathrm{c}$ & $3,91 \mathrm{c}$ & 0,132 \\
\hline Fibra em detergente neutro (\% da MS) & $79,76 a$ & $78,73 a$ & $73,50 \mathrm{~b}$ & $71,12 b$ & $73,40 \mathrm{~b}$ & $73,56 b$ & 0,456 \\
\hline Fibra em detergente ácido (\% da MS) & $49,79 a$ & $49,24 a$ & $45,53 b$ & $45,27 b$ & $45,68 b$ & $45,94 b$ & 0,298 \\
\hline $\mathrm{pH}$ & 4,13a & 3,85b & 3,97b & $3,87 \mathrm{~b}$ & $3,45 c$ & $3,50 c$ & 0,035 \\
\hline $\mathrm{N}-\mathrm{NH}_{3}{ }^{2}$ & $2,06 \mathrm{c}$ & $1,73 \mathrm{c}$ & $2,52 b$ & $2,16 \mathrm{bc}$ & $3,10 \mathrm{a}$ & $2,59 b$ & 0,001 \\
\hline
\end{tabular}

1 Erro-padrão da média.

2 Em \% no N-total

Médias seguidas de letras diferentes nas linhas diferem entre si $(\mathrm{P}<0,05)$ pelo teste Tukey. 
Não houve efeito significativo $(\mathrm{P}>0,05)$ do espaçamento de plantio, na mesma idade de corte, sobre a composição bromatológica da fração feixe. Esses dados corroboram revisões realizadas por Pate et al. (2002), Pereira Jr. (1984) e Paranhos (1972), que, pesquisando espaçamentos entre linhas de 1,00 m e 1,80 m, não observaram alteração na composição bromatológica das plantas.

O teor de matéria seca da cana-de-açúcar da fração feixe foi influenciado $(\mathrm{P}<0,05)$ pela idade de corte. A canade-açúcar com 420 dias apresentou, em média, teores mais elevados de matéria seca (25,15\% e 25,48\%) em comparação às idades de 240 dias (21,30\% e 21,90\%) e 180 dias (16,00\% e 16,63\%). Freitas et al. (2006b) encontraram teores de 26\% e 27,8\% de MS na cana-de-açúcar colhida aos 330 dias (maio) e 390 dias (junho), respectivamente. O aumento do teor de matéria seca ocorre com o avanço do estádio vegetativo da planta e, na cana-de-açúcar, o fator que mais determina o aumento do teor de matéria seca são os carboidratos solúveis, quase que exclusivamente a sacarose. A variedade RB72-454 utilizada neste experimento é de acúmulo médio-tardio, ou seja, com teor de sacarose superior ao de outras variedades no meio da safra (julho, agosto, setembro).

Os mais baixos teores de matéria seca encontrados neste estudo para a cana-de-açúcar de 420 dias estão relacionados à época de colheita do material (janeiro), caracterizada pelo acúmulo tardio de sacarose na variedade RB72-454 e pela precipitação característica, que aumenta a participação de água na planta.

Neste trabalho, $\mathrm{o}^{\circ}$ brix sofreu efeito $(\mathrm{P}<0,05)$ da idade de corte, pois os menores valores foram encontrados para a cana-de-açúcar colhida em janeiro, com 180 dias (6,27 e $6,90)$. Para a cana de 420 dias, os teores encontrados foram próximos aos relatados por Rodrigues et al. (1997), de 17,8 para a mesma variedade com 450 dias de idade. Todavia, foram inferiores aos observados por Shigaki et al. (2003), de 21,93, com cana-de-açúcar RB72-454 cortada aos 330 dias (setembro).

A época em que é realizada a colheita da cana-de-açúcar é determinante do teor de sacarose nos colmos, uma vez que o acúmulo de sacarose é fortemente influenciado pelas condições ambientais, desfavoráveis ao crescimento e desenvolvimento vegetativo. Neste estudo, a cana-deaçúcar colhida em janeiro, aos180 e 420 dias, não sofreu período de restrição hídrica, o que seguramente prejudicou o acúmulo de sacarose. Além disso, houve alta precipitação, típica nessa época do ano, que atua como fator diluente da sacarose que estava presente no colmo das plantas.

Considerando a colheita realizada em julho, para a cana-de-açúcar com 240 dias, os valores de brix foram inferiores ao relatado na literatura, de 10,21 e 10,86 (0,90 m e 1,30 m, respectivamente), o que difere do valor obtido por Banda \& Valdez (1976), de 14,5. Esse baixo acúmulo de açúcar solúvel, representado pelo ${ }^{\circ}$ brix, é reflexo da maturação intermediária-tardia da variedade utilizada no experimento.

A fração de matéria mineral diferiu significativamente $(\mathrm{P}<0,05)$ entre as idades de corte. Os maiores valores foram obtidos para cana com 180 dias e decresceram com o avançar da idade, variando de 4,41 a 7,25\%. Os valores encontrados estão dentro da faixa de valores compilados por Nussio et al. (2006), de 0,81 e 6,42\% de matéria mineral, com exceção da cana com 180 dias (7,08 e 7,25\%), entretanto, foram próximos aos obtidos por Kung Jr. \& Stanley (1982) em cana-de-açúcar com 180 dias de idade, de 7,43\%.

Neste trabalho, os teores de extrato etéreo da cana-deaçúcar sofreram efeito significativo $(\mathrm{P}<0,05)$ da idade de corte. Os maiores valores foram encontrados para canade-açúcar com 180 dias, de 2,85 e 2,75\%, enquanto a média para cana-de-açúcar de 240 e 420 dias foi de 2,12\%. Kung Jr. \& Stanley (1982) relataram valores de 3,2 e 2,6\% para canade-açúcar com 180 dias e 270 dias, respectivamente. Valores compilados por Pinto et al. (2003) indicam média de 1,47\% de extrato etéreo e por Mello et al. (2006), de 0,68\% extrato etéreo, para cana-de-açúcar com 450 dias.

Os teores de proteína bruta variaram $(\mathrm{P}<0,05)$ de acordo com as idades de corte. As médias para cana de 180, 240 e 420 dias foram, respectivamente, 5,$49 ; 6,18$; e $3,47 \%$. Os valores encontrados para a cana-de-açúcar de 420 dias foram próximos aos relatados por Andrade et al. (2004) e Mello et al. (2006), de 3,2\% e 3,3\% de proteína bruta, respectivamente. Os teores médios de proteína bruta para a idade de corte de 240 dias foram superiores aos da cana com 180 dias (Tabela 1), fato contrário ao esperado e relatado na literatura (Banda \& Valdez, 1976; Kung Jr. \& Stanley, 1982), uma vez que a proteína dessa espécie vegetal se encontra principalmente nas folhas, que são abundantes nas fases de desenvolvimento da planta. No entanto, o maior teor de proteína bruta aos 240 dias provavelmente deveu-se ao maior número de folhas (observação visual) e à maior atividade enzimática presente nesta fase, uma vez que o crescimento da cana colhida aos 240 dias ocorreu no período de novembro a julho, todo o período do verão, que apresenta condições climáticas ideais ao crescimento vegetativo da cana-de-açúcar.

Ressalta-se que a cana-de-açúcar colhida aos 240 dias teve seu crescimento entre novembro e julho, e se beneficiou de todo o período do verão, que apresenta condições climáticas ideais ao crescimento vegetativo da cana-deaçúcar. Os valores dos componentes de parede celular, 
expressos em \%FDN, \%FDA e \%lignina, apresentaram o mesmo comportamento da proteína bruta e matéria mineral, decrescendo com o avançar da idade. Os dados estão de acordo com as amplitudes de variação observadas por Azevêdo et al. (2003), Fernandes et al. (2003) e Freitas et al. (2006b).

A idade de corte teve efeito significativo $(\mathrm{P}<0,05)$ sobre a composição em FDN. O menor teor de FDN foi encontrado na cana colhida aos 420 dias (valor médio de 60,38\%) como efeito da diluição dos componentes da parede celular, em decorrência do aumento do teor de sacarose promovido pela maturação da planta.

Os dados apresentados neste trabalho para o teor de FDN são superiores aos descritos para a mesma variedade por Oliveira etal.(1999), Shigaki etal. (2003), Santos etal.(2006), em torno de 40,86; 46,96; e 48,60\%, respectivamente. Entretanto, assim como observado por Rodrigues et al. (2001) e Freitas et al. (2006a), o maior teor de FDN observado neste trabalho pode ser resultado do acúmulo tardio de sacarose, característico da variedade RB72-454. Na cana colhida aos 180 e 240 dias, as médias foram de 75,61 e $68,13 \%$ de FDN, respectivamente. Independentemente da idade de corte, os teores de FDN encontrados são superiores aos recomendados por Rodrigues et al. (1997), que preconizam valores abaixo de $52 \%$, uma vez que a fibra pode limitar a ingestão de cana-de-açúcar, comprometendo o desempenho animal.

O efeito do amadurecimento tardio da variedade utilizada neste experimento também afetou $(\mathrm{P}<0,05)$ os teores de FDA e lignina. O teor médio de FDA para as idades de corte de 180, 240 e 420 dias foram de 43,59; 42,57 e 36,22\%, respectivamente. Os dados obtidos estão próximos aos relatados por Kung Jr. \& Stanley (1982), que encontraram valores de 41,5\% FDA para cana com 180 dias e 40,8\% FDA para 270 dias. Considerando a cana-de-açúcar com 420 dias, os valores encontrados (36,61 e 35,54\%) são superiores à média relatada por Pinto et al. (2003), de 31,12\%, e Teixeira et al. (2004), de 30,3\%. Valores inferiores são relatados na literatura por Oliveira et al. (1999), de 25,5\% FDA; Santos et al. (2006), de 26,2\% FDA; e Freitas et al. (2006a), de $32,3 \%$ FDA.

Os maiores teores de FDA observados neste trabalho, em comparação a trabalhos de outros autores, devem-se ao efeito da época de colheita. É provável que houve mobilização dos carboidratos solúveis para nova fase de crescimento vegetativo, aumentando a participação do FDA na análise.

O teor de lignina sofreu efeito significativo $(\mathrm{P}<0,05)$ da idade de corte; o maior valor foi encontrado para a cana-deaçúcar com 240 dias, com valor médio de 7,2\%, próximo do apresentado por Banda \& Valdez (1976), de 6,24\%. O menor valor observado para a cana-de-açúcar colhida com 180 dias (5,26\% lignina) é resultado da colheita de material muito novo, que ainda não completou a fase de diferenciação e maturação dos tecidos para iniciar a intensa fase de deposição de lignina. No caso da cana-de-açúcar com 420 dias (4,86\%), o menor teor de lignina está relacionado à diluição dos componentes da parede celular, em decorrência do acúmulo de sacarose, como pode ser observado pelo ${ }^{\circ}$ brix.

Considerando a cana-de-açúcar colhida aos 420 dias, o valor médio foi de 4,86\% lignina, dentro da faixa de variação obtida por Andrade et al. (2004), que analisaram 60 variedades de cana-de-açúcar colhidas aos 360 dias e relataram variação de 2,71 a 7,11\% no teor de lignina.

$\mathrm{Na}$ análise bromatológica da fração toco, verificou-se a composição do material que permanece na soqueira em situação de colheita mecanizada. Os menores valores de matéria seca foram encontrados para os tocos da cana-deaçúcar colhida aos 180 dias de crescimento. O teor de matéria seca para a fração toco de 240 dias não diferiu $(\mathrm{P}>0,05)$ entre os tocos da cana-de-açúcar colhida aos 420 dias, o que indica que os perfilhos mais desenvolvidos já teriam iniciado o processo de acúmulo de sacarose nos colmos mais velhos (Segato et al., 2006).

Os valores de proteína bruta do material que permaneceria no campo (fração toco), 3,54, 4,79 e 2,89\%, foram inferiores àquela do feixe $(5,49,6,18$ e 3,47\%), em virtude da ausência de folhas nessa fração, que contribuiria para aumentar o teor de nitrogênio na análise (Tabela 1). O mesmo comportamento foi observado para os teores de FDN e FDA. Comparando os resultados obtidos com a cana colhida aos 180, 240 e 420 dias, observa-se redução de 12,68; 24,62 e 17,60\% no teor de FDN e de 14,66, 23,45 e $13,32 \%$ de FDA na fração toco, o que indica que a presença dos carboidratos solúveis foi o fator diluente do teor fibra.

As silagens de cana colhida aos 90 dias de crescimento apresentaram, todas, maiores concentrações dos componentes da fibra e proteína e redução no teor de matéria seca em relação aos valores das canas-de-açúcar correspondentes antes da ensilagem (Tabela 1). A única exceção foi o teor de matéria seca da cana colhida aos 180 dias.

A análise para teor de matéria seca das silagens indicou diferença significativa $(\mathrm{P}<0,05)$ para as idades de corte, uma vez que os menores teores foram determinados na silagem de cana-de-açúcar com 180 dias (18,41\%).

Verificou-se aumento do teor de matéria seca em duas das seis observações (Tabela 1). O aumento no teor de matéria seca foi observado para a silagem de cana-deaçúcar de 180 dias, possivelmente em razão da maior produção de efluentes que migraram para a parte de baixo do silo experimental, parte essa que foi descartada na amostragem. 
Rotz \& Muck (1994) afirmaram que as perdas médias na produção de silagem variam de 14 a $24 \%$, de modo que aproximadamente a metade das perdas ocorre durante a estocagem e que, geralmente, a soma das perdas físicas ou a exaustão de nutrientes como os carboidratos solúveis ocasionam aumentos de 3 a 12 pontos percentuais nos teores de FDN na matéria seca de silagens produzidas e pequena variação, para menos ou para mais, na concentração de proteína.

A redução do teor de matéria seca do material in natura para o material ensilado foi de 5,74\% para a idade de 240 dias e $6,24 \%$ para a idade de 420 dias. De acordo com as pesquisas de Pedroso et al. (2007) e Lopes et al. (2007), as reduções de matéria seca obtidas foram de 14,76 e 23\% para cana-de-açúcar com 360 e 540 dias de crescimento, respectivamente. O corte aos 180 dias de idade proporcionou teores de matéria seca abaixo de $20 \%$, o que pode interferir na conservação da massa ensilada e aumentar as perdas de nutrientes por efluentes. Considerando o teor de matéria seca, o corte aos 420 dias resulta em material mais adequado à conservação.

O conteúdo de matéria seca determina as alterações que podem ocorrer durante o processo de fermentação da forragem. Silagens com menos de 30\% de MS podem apresentar elevadas quantidades de efluentes e altos teores de nitrogênio amoniacal, resultante da ação de Clostridium. Neste sentido, este trabalho comprova que o alto teor de umidade no material fresco contribuiu com altos teores de nitrogênio amoniacal (1,73 a 3,10\% da proteína total).

Os teores de proteína bruta na matéria seca das silagens de cana-de-açúcar diferiram $(\mathrm{P}<0,05)$ entre as idades de corte, seguindo a mesma tendência observada para os valores da composição do material in natura, ou seja, maiores teores para cana de 240, 180 e 420 dias.

Os teores de FDN neste trabalho foram superiores aos citados por Pedroso et al. (2007), que obtiveram valores de $59,5 \%$ para cana com 12 meses de crescimento e Nussio et al. (2006), que, em revisão de análises realizadas no laboratório de bromatologia da USP/ESALQ, citaram como valor máximo encontrado 72,42\% de FDN. De acordo com os dados deste estudo, houve aumento médio de 43,59 para 49,51\%; 42,57 para 45,38\% e 36,22 para 45,81\% para os teores de FDA do material in natura e ensilado nas idades de 180, 240 e 420 dias, respectivamente.

Silagens bem manejadas apresentam aumento nas concentrações de FDN e FDA, que variam entre 1 e $6 \%$ em relação aos teores originalmente presentes na forragem, como consequência da perda de carboidratos solúveis por respiração (Rotz \& Muck 1994). O aumento no teor de FDN após o processo de ensilagem foi de magnitudes de 4,8; 6,13 e 21,69\% para a silagem de cana-de-açúcar colhidas aos 180, 240 e 420 dias, respectivamente. Pedroso et al. (2007) e Lopes et al. (2007) obtiveram aumento da fração FDN de $12,5 \%$ e $21,6 \%$, respectivamente. De acordo com os autores, esse resultado está relacionado à redução nos teores dos carboidratos solúveis no processo de fermentação e, segundo Schmidt et al. (2007), o aumento nos constituintes da parede celular é proporcional ao maior consumo de carboidratos solúveis. Esse comportamento foi observado neste trabalho, pois a silagem de cana-de-açúcar colhida aos 420 dias apresentou maior aumento percentual nos constituintes da parede celular.

Os valores de $\mathrm{pH}$ da cana-de-açúcar ensilada situaram-se entre 3,50 e 4,43. De modo geral, o pH nas silagens foi mais alto para a cana mais nova e diminuiu com o aumento da idade. O menor teor de matéria seca na cana de 180 dias e a menor proporção de carboidratos solúveis podem ter limitado o processo de fermentação e a redução do pH.

A maior parte dos trabalhos com silagem de cana-deaçúcar aponta valores de pH entre 3,2 e 3,8 (Pedroso, 2007; Lopes et al., 2007; Santos et al., 2006). Entretanto, Schmidt et al. (2007) ressaltaram que estudos de dinâmica de fermentação de silagens de cana-de-açúcar descrevem valores de pH próximos a 4,0 no segundo dia de fechamento do silo. Esses autores afirmam que, em substratos com alto teor de carboidratos solúveis, como a cana-de-açúcar, o pH não é inibitório para as leveduras, que podem se desenvolver nesses ambientes sob pH de 3,5 ou inferior.

\section{Conclusões}

Enquanto os dois espaçamentos de plantio testados não têm efeito significativo, a idade de corte da cana-deaçúcar afeta sua composição química. Os componentes analisados nas diferentes idades são diretamente correlacionados ao acúmulo de sacarose, resultante do processo de maturação da planta. Desta forma, os constituintes estruturais reduziram em porcentagem com o aumento no teor de carboidratos solúveis. O baixo teor de matéria seca presente no material in natura comprometeu o adequado processo de fermentação no silo, que resultou em altos teores finais de fibra em detergente neutro e fibra em detergente ácido.

\section{Agradecimentos}

Ao CNPq, pelo apoio financeiro ao primeiro autor do trabalho. Aos proprietários das fazendas Bela Aurora, Bela Vista e Santo André, nas pessoas de Marco Baggio Filho, Marco Baggio Netto e Nelson Simionato, pela 
disponibilização das áreas experimentais, equipamentos e pessoal para a realização do trabalho.

\section{Literatura Citada}

ANDRADE, J.B.; FERRARI JR., E.; POSSENTI, R.A. et al. Composição química de genótipos de cana-de-açúcar em duas idades, para fins de nutrição animal. Bragantia, v.63, n.3, p.341-349, 2004.

ASSOCIATION OFFICIAL ANALYTICAL CHEMISTS - AOAC. Official methods of analysis. 15.ed. Washington: 1990. 1015p.

AZEVÊDO, J.A.G.; PEREIRA, J.C.; CARNEIRO, P.C.S. et al. Avaliação da divergência nutricional de variedades de cana-deaçúcar (Saccharum spp.). Revista Brasileira de Zootecnia, v.32, n.6, p.1431-1442, 2003.

BANDA, M.; VALDEZ, R.E. Effect of stage of maturity on nutritive value of sugar cane. Tropical Animal Production, v.1, n.2, p.94-97, 1976.

FERNANDES, A.M.; QUEIROZ, A.C.; PEREIRA. J.C. et al. Composição químico-bromatológica de variedades de cana-deaçúcar (Saccharum spp L.) com diferentes ciclos de produção (precoce e intermediário) em três idades de corte. Revista Brasileira de Zootecnia, v.32, n.4, p.977-985, 2003.

FREITAS, A.W.P; PEREIRA, J.C.; ROCHA, F.C. Avaliação da divergência nutricional de genótipos de cana-de-açúcar (Saccharum spp.). Revista Brasileira de Zootecnia, v.35, n.1, p.229-236, 2006a.

FREITAS, A.W.P.; PEREIRA, J.C.; ROCHA, F.C. Características da silagem de cana-de-açúcar tratada com inoculante bacteriano e hidróxido de sódio e acrescida de resíduo da colheita de soja. Revista Brasileira de Zootecnia, v.35, n.1, p.48-59, 2006b.

GOERING, H.K.; Van SOEST, P.J. Forage fiber analysis (Apparatus, reagents, procedures and some applications). Washington: USDA, 1970. (Agricultural Handbook, 379).

KUNG JR., L.; STANLEY, R.W. Effect of stage of maturity on the nutritive value of whole-plant sugarcane preserved as silage. Journal of Animal Science, v.54, n.4, p.689-696, 1982.

LOPES, J.; EVANGELISTA, A.R.; ROCHA, G.P. Valor nutricional da silagem de cana-de-açúcar acrescida de uréia e aditivos absorventes de umidade. Revista Brasileira de Zootecnia, v.36, n.4, p.1155-1161, 2007.

MELLO, S.Q.; FRANÇA, A.F.S; LIMA, M.L.M. et al. Parâmetros do valor nutritivo de nove variedades de cana-de-açúcar cultivadas sob irrigação. Ciência Animal Brasileira, v.7, n.4, p.373-380, 2006.

NUSSIO, L.G.; SCHMIDT, P.; SCHOGOR, A.L.B. et. al. Cana-de-açúcar como alimento para bovinos. In: SIMPÓSIO SOBRE MANEJO ESTRATÉGICO DA PASTAGEM, 3., 2006, Viçosa, MG. Anais... Viçosa, MG: Universidade Federal de Viçosa, 2006. p.277-328.

OLIVEIRA, M.D.S.; TOSI, H.; SAMPAIO, A.A.M. et al. Avaliação de duas variedades de cana-de-açúcar submetidas a diferentes tempos de armazenamento. Pesquisa Agropecuária Brasileira, v.34, n.8, p.1435-1442, 1999.

PARANHOS, S.B. Espaçamentos e densidades de plantio em cana-de-açúcar. 1972. 112f. Tese (Doutorado em Agronomia) Escola Superior de Agricultura Luiz de Queiroz, Piracicaba, 1972.
PATE, F.M.; ALVAREZ, J.; PHILLIPS, J.D. Sugarcane as cattle feed: production and utilization. Gainesville: Departament of Animal Science, University of Florida, Institute of Food and Agricultural Sciences, 2002. p.2-8. (Bulletin, 844).

PEDROSO, A.F.; NUSSIO, L.G.; LOURES, D.R.S. et al. Efeito do tratamento com aditivos químicos e inoculantes bacterianos nas perdas e na qualidade de silagens de cana-de-açúcar. Revista Brasileira de Zootecnia, v.36, n.3, p.558-564, 2007.

PEREIRA JR., A.C.G. Efeitos da irrigação e do espaçamento no desenvolvimento e na produção de três variedades de cana-de-açúcar (Saccharum spp.). 1984. 123f. Dissertação (Mestrado em Irrigação e Drenagem) - Escola Superior de Agricultura Luiz de Queiroz, Piracicaba, 1984.

PINTO, A.P.; PEREIRA,E.S.; MIZUBUTI, I.Y. Características nutricionais e formas de utilização da cana-de-açúcar na alimentação de ruminantes. Semina: Ciências Agrárias, v.24, n.1, p.73-84, 2003.

RODRIGUES, A.A.; PRIMAVESI, O.; ESTEVES, S.N. Efeito da qualidade de variedades de cana-de-açúcar sobre seu valor como alimento para bovinos. Pesquisa Agropecuária Brasileira, v.32, n.12, p.1333-1338, 1997.

RODRIGUES, A.A.; CRUZ, G.M.; BATISTA, L.A.R. et al. Qualidade de dezoito variedades de cana-de-açúcar como alimento para bovinos. In: REUNIÃO ANUAL DA SOCIEDADE BRASILEIRA DE ZOOTECNIA, 38., 2001, Piracicaba. Anais... Piracicaba: Sociedade Brasileira de Zootecnia, 2001. (CD-ROM).

ROTZ, C.A.; MUCK, R.E. Changes in forage quality during harvest and storage. In: FAHEY JR., G.C.; MOSER, L.E.; MERTENS, D.R. et al. (Eds.) National conference on forage quality, evaluation, and utilization. Madison: University of Nebraska, 1994. p.828-868.

SANTOS, R.V; EVANGELISTA, A.R.; PINTO, J.C. et al. Composição química da cana-de-açúcar (Saccharum spp.) e das silagens com diferentes aditivos em duas idades de corte. Ciência e Agrotecnologia, v.30, n.6, p.1184-1189, 2006.

SCHMIDT, P.; MARI, L.J.; NUSSIO, L.G. et al. Aditivos químicos e biológicos na ensilagem de cana-de-açúcar. 1. Composição química das silagens, ingestão, digestibilidade e comportamento ingestivo. Revista Brasileira de Zootecnia, v.36, n.5, p.1666-1675, 2007.

SEGATO, S.V.; MATTIUZ, C.F.M.; MOZAMBANI, A.E. Aspectos fenológicos da cana-de-açúcar. In: SEGATO, S.V.; PINTO, A.S.; JENDIROBA, E. et. al. (Eds.) Atualização em produção de cana-de-açúcar. 1.ed. Piracicaba: Livroceres, 2006. p.19-36.

SHIGAKI, F.; FREITAS, N.; BERTO, A. et al. Avaliação do valor nutritivo de variedades de cana-de-açúcar para alimentação bovina. In: REUNIÃO ANUAL DA SOCIEDADE BRASILEIRA DE ZOotecniA, 40., 2003, Santa Maria. Anais... Santa Maria: Sociedade Brasileira de Zootecnia, 2003. (CD-ROM).

SILVA, D.J.; QUEIROZ, C. Análise de alimentos (Métodos químicos e biológicos). Viçosa, MG: Universidade Federal de Viçosa, 2002. 235p.

TEIXEIRA, C.B. Determinantes da degradabilidade entre clones de cana-de-açúcar no rúmen de bovinos. 2004. 72f. Dissertação (Mestrado em Zootecnia) - Universidade Federal de Lavras, Lavras, 2004. 